\title{
FDI, Finance and Growth: Further Empirical Evidence from a Panel of 73 Countries
}

\author{
Dimitrios Asteriou $^{1} \&$ Argiro Moudatsou ${ }^{2}$ \\ ${ }^{1}$ Professor of Quantitative Methods, Hellenic Open University, Greece \\ ${ }^{2}$ Associate Professor in Economics and Finance, Technological Educational Institute of Crete, Greece \\ Correspondence: Dimitrios Asteriou, Professor of Quantitative Methods, Hellenic Open University, Greece
}

Received: August 1, 2014

Accepted: August 29, 2014

Available online: October 9, 2014

doi:10.11114/aef.v1i2.480

URL: http://dx.doi.org/10.11114/aef.v1i2.480

\begin{abstract}
The aim of this study is to investigate whether the level of financial development can make a significant contribution to the Foreign Direct Investment's (FDI) positive impact on economic growth. In other words, to examine whether the contribution of FDI on growth is relatively more important in countries with well-developed financial markets compared to those with the less-developed ones. The time period of the empirical research spans from 1988-2009, using yearly macroeconomic data for a sample of 73 developing countries. Our empirical methodology consists of panel-growth regressions. Our results suggest that the FDI make substantial contribution to growth where financial systems function effectively, such as high-income countries, while the FDI impact is found to be insignificant in cases where relatively weaker financial systems exist.
\end{abstract}

Keywords: Foreign Direct Investment, Financial Development, Panel Data Regressions

\section{Introduction}

The last two decades have witnessed huge amounts of foreign direct investment (FDI) flows among the developed and developing world. The FDI has been seen as an opportunity for economic development and growth. The widespread belief was that FDI has numerous benefits for the domestic economy through technological diffusion, managerial skills, well-trained employees and so on. Therefore several countries adopted new policies to liberalize their capital accounts and made regulatory changes in order to create more favorable conditions for the FDI attraction. However, the different experiences of developing countries have presented mixed effects for the so-called positive contribution of FDI inflows on growth (see Borensztein et al., 1998; De Mello, 1999; Rodriguez-Clare et al., 2000; Reisen and Soto, 2001 among others). Despite the fact that the theories emphasize the important role of the FDI in modernizing the national economy and enhancing the economic growth, the empirical evidence, both at firm and country level is contradictory. For example, when looked at the plant level data in Venezuela, Aitken and Harrison (1999) show that the net effect of FDI on productivity is quite small. Namely, FDI increases the productivity of the firms that receive FDI but lowers that in domestic firms. Results are similar for Morocco (Haddad and Harrison, 1993). However, a positive effect of FDI spillovers has been found for Mexico (Blomström, and Persson, 1983), Uruguay (Kokko, Tansini and Zejan, 1996) and Indonesia (Sjoholm, 1999).

In the relevant literature, it has been emphasized that the spillovers effect can only be efficient under the certain characteristic of the environment in the host country. These conditions together determine the absorptive capacity of the technology spillovers of the host country. According to Hermes and Lensink (2003) the positive effect of FDI can only be created under the existence of sufficient absorptive capacity. The importance of the local conditions is stressed in Borensztein et al. (1998). They suggest that FDI flows and human capital are complementary rather than substitute in the process of technological diffusion and therefore a certain level of human capital in the host country is necessary to take the advantages of FDI flows.

In a different strand of the economic growth literature the emphasis is given on the role of financial development (see Greenwood and Jovanovic, 1990; Levine and Renelt, 1992; King and Levine, 1993a; 1993b; Levine and Zervos, 1998; Rajan and Zingales, 1998; Levine et al., 2000 among others). Some researchers argue that the efficiency of the technological diffusion is closely associated with the presence of a well-developed financial system in the host economy. This aspect is supported by Alfaro et al. (2004). They first introduce the importance of the country's financial 
environment in the FDI-Growth literature. It is argued that the well-functioning financial environment will allow FDI to operate in a better way since there are low market distortions and therefore the free flow of knowledge among firms will be facilitated. This important characteristic of the host country's financial structure has not been investigated systematically in conjunction with the role of FDI and in a panel data framework of a large number of developing countries. Therefore the contribution of this study focuses on the development of domestic financial system as a precondition for the host country to take the advantage of FDI flows. We investigate whether the level of financial development can make a significant contribution to the FDI's positive impact on economic growth or in other words, whether the contribution of FDI to growth is higher in countries with well-developed financial markets compared to those with the less-develop ones.

The rest of this paper is structured as follows. Section 2 presents the data, section 3 the empirical methodology and section 4 presents the empirical results. Finally, section 5 summarizes and concludes.

\section{The Data Set}

Our sample consists of data for 73 developed and less developed countries for the period 1975-2009. The main source of our data sources is the World Bank's "World Development Indicators", which provided us significant amount of data related to countries' macroeconomic variables such as trade, inflation, external investments, GDP growth etc. For the financial indicators the sources used are the "World Bank Financial Structure Database" and the IMF's "International Financial Statistics".

In the finance-growth literature, creating indicators to measure cross-country data is a rather complex issue. The difficulty concerns the accuracy and comparability of the cross-sectional data of the economies. However, we use the indicators that introduced by Beck, Demirgüç-Kunt and Levine (2000). They introduce a new database of financial development and structure across countries based on three categories. These are size, activity and efficiency of financial intermediaries and markets. We employ an array of variables related to financial development and growth. These indicators can be divided into two groups. Those associated to the stock market and those associated to the financial intermediaries. For the first set of indicators, six measurements are included:

Central Bank Assets to Total Financial Assets (CBATA) is an indicator that measures the entire financial capital of the economy as accounted for by the capital of the central bank.

Total Financial Assets are the whole assets of the Central Bank, banks' deposit money, and other financial assets.

Bank Deposits to GDP and Financial System Deposits to GDP (BDGDP and FDGDP respectively) are absolute size indicators that measure the value of the bank and whole financial system deposits with respect to the economy of the country.

To evaluate the absolute size of the economies we use the Liquid Liabilities (LLGDP) measure. This equals currency plus demand and interest-bearing liabilities of the banks and other financial intermediaries divided by GDP. This measure is proposed by King and Levine (1993b). The idea behind this variable is that the size of the financial sector is positively correlated with the provision of financial services. We use this variable due to the fact that it is the broadest used measure of financial depth, as Beck, Demirgüç-Kunt and Levine (2000) argued.

The aforementioned measures do not distinguish whether the claims of the financial intermediaries are in the public or the private sector. Therefore, Beck, Demirgüç-Kunt and Levine (2000) construct the measure of activity of intermediaries', which focus solely on the claims on the private sector. These include the Private Credit by the Deposit Money Banks to GDP (PCRDBGDP) and Private Credit by the Deposit Money Banks and Other Financial Institutions to GDP (PCRDBOFGDP). Beck, Demirgüç-Kunt and Levine (2000) state that both measures exclude credit issued to the private sector as opposed to credit issued to governments and public enterprises and focus on credit issued by intermediaries rather than the central bank.

In the second category of measures, we include stock market variables as indicators of the size, activity and efficiency of the stock markets and we use three stock market related variables:

Stock Market Capitalization Ratio to GDP (STMKTCAP), which equals the value listed shares divided by GDP. It is used by Levine and Zervos (1998), and later Beck, Demirgüç-Kunt and Levine (2000) and Alfaro et al. (2004). Many researchers used STMKTCAP as an indicator of market development.

Stock Market Total Value Traded to GDP (STVALTRADED) is an indicator that measures the activity or liquidity of stock markets. As defined by Beck, Demirgüç-Kunt and Levine (2000) it is total shares traded on the stock market exchange divided by GDP.

Stock Market Turnover Ratio (STTURNOVER) is used as an indicator of stock market efficiency. It is defined as the ratio of the value of total shares traded over market capitalization. It measures the activity and liquidity of the stock market relative to its size. According to Beck, Demirgüç-Kunt and Levine (2000) emphasizing the view that a small but 
active stock market will have high turnover ratio compared to a large, less liquid stock market will have lower turnover ratio.

FDI, is measured as the net inflows to the economy over GDP, which equals the sum of equity capital, reinvestment of earnings, other long-term capital, and short-term capital as shown in the balance of payments in the World Development Indicators database.

Finally, we used a set of control variables, such as: inflation (INF) to be used as a proxy of macroeconomic stability, and the trade ratio (TRD) which equals the sum of exports plus imports to total output in order to measure the openness in international trade

\section{Methodology}

To test the hypothesis that FDI has a positive effect on economic growth and also that financial development makes significant contributions to this process, we use a dynamic panel-data methodology to estimate cross-country growth regressions. Firstly, we construct a model to look at the direct effect of FDI on growth and estimate the following equation by OLS:

$$
G D P P C G R_{i t}=\alpha_{1 i}+\beta_{1 i} F D I_{i t}+\beta_{2 i} C O N T R O L S_{i t}+v_{1 i t}
$$

where $G D P P C G R_{i t}$ (the dependent variable) is per capita GDP growth rate, in country $i$ and time period $t,{ }_{1 i}$ is a country-specific effect, $F D I_{i t}$ is the foreign direct investment to GDP ratio for each country $i$, and CONTROLS $S_{i t}$ is a set of control variables, such as the trade volume and the inflation rate. Our sample consists of countries in different levels of development. Therefore, in order to have homogeneous data, after estimating the regression for all countries, we split the initial group into three different sub-groups: high-income, middle-income and low-income countries.

Similarly, in order to test the direct effect of the financial market size, activity and efficiency, we run the following regression, initially, for all countries and then for the three sub-groups.

$$
\text { GDPPCGR }_{i t}=\alpha_{2 i}+\beta_{3 i} \text { FINANCE }_{i t}+\beta_{4 i} \text { CONTROLS }_{i t}+v_{2 i t}
$$

where FINANCE $_{i t}$ is the set of the various financial development proxy indices described above.

Finally, in order to investigate the role of FDI on growth through the financial markets development effect, we insert as an additional regressor an interactive term (see Hermes and Lensink, 2003). Thus, we use the following equation model:

$$
\text { GDPPCGR }_{i t}=\alpha_{3 i}+\beta_{5 i}\left(F D I_{i t} * \text { FINANCE }_{i t}\right)+\beta_{6 i} \text { CONTROLS }_{i t}+v_{3 i t}
$$

where the variables are defined similarly to equations (1) and (2) above.

\section{Empirical Results}

To estimate the direct effect of FDI on economic growth, we run the basic regression model (1). First, we estimate the model for the whole sample (all countries) and then we split it in three sub-groups (high-income, middle-income and low-income countries). The results are presented in Table 1, and FDI has, as expected, a positive significant effect, but not too strong (it is near zero) on economic growth for all groups, with the exception of the low-income group. Regarding the control variables, INF has statistically significant and negative impact on the rate of growth almost in all groups, except the high-income group. That is consistent with the Boyd et al. (2001) and Alfaro et al. (2002) findings. It seems that high inflation slows down the financial deepening and then through its channels the adverse effect spreads on to economic growth. Finally, the trade ratio, TRD has a strong positive relationship on growth for all groups except the high-income countries (which was as expected) but the coefficients are substantially close to zero again. So, we do not have too much to claim from this regression model.

Then, we run regression model (2) in order to investigate the pure influence of the financial development proxies over the economic growth. Table $2 \mathrm{a}$, shows the results for the first case where we use the whole sample of 73 countries. For each case the FINANCE variable proxy used is denoted at the top of each regression model reported in the Table. The results appear to be mixed. First, we obtain significant results only for PRCDBGDP, PCRDBOFGDP and STMKTCAP. For the first two cases, the variables that found to be significant measure the activity and liquidity of financial intermediaries. The effect of these two variables is found to be significant and negative suggesting that they hinder growth. On the other hand the STMKTCAP was found to be significant and positive, thus promoting growth. For all other proxy measures we do not even have statistically significant coefficients, while in most cases the effect is negative. Therefore, contrary to other studies, the direct effect of financial market variables for the sample chosen seems to be ambiguous. Finally, the INF variable has a negative and significant correlation with growth (the coefficients are again very small), and the TRD variable has a positive but very low effect on growth.

Then we estimate the same model (the effect of financial market variables on growth) using data only for the first sub-group, i.e. the high-income countries. The results are similar and somehow strengthen those obtained in Table 2a. The financial variables PCRDBGDP, PCRDBOFGDP, STMKTCAP, STTURNOVER, CBATA and BDGDP are 
statistically significant. When looking at the coefficients, most of them are still negative and near to zero, with the exception of STMKTCAP which seems to have a strong positive effect on growth. Thus, our results suggest that it is the stock markets that affect growth and not financial intermediation in general. The INF variable is entering the model with statistically insignificant coefficients and the TRADE coefficients are positive and significant for most cases, as expected.

The regression results for the middle-income countries are presented in Table 2c. These are quite different than those of obtained for the high-income countries. The financial market variables that have statistically significant coefficients are now STMKTCAP and STTURNOVER. Both of those stock market development proxies seem to have a strong positive influence on growth. All other financial proxies are insignificant (and most of them are negative). The TRD and INF coefficient estimates become more consistent with the literature and support the idea that there is negative correlation between the inflation and growth and a positive correlation between the TRD and growth.

Finally, Table $2 \mathrm{~d}$ reports the regressions results for the low-income group. This group mostly consists of sub-Saharan African countries such as Ghana, Senegal, Togo and so forth. The major characteristic of these countries is the insufficient level of domestic financial system and consequently it is likely that FDI has no positive effect on their economic growth. However, the pure effect of the level of development of the domestic financial system on growth is ambiguous. The results shows that none of the financial development proxy variables are significant, which is expected since the stock market proxies that were significant before, was probably due to the fact that the stock markets were indeed developed in the groups of countries examined before, something that can't be true in this case. Finally, INF has a negative significant effect on growth almost for all variables however the coefficients are rather small and close to zero.

Table 1. The Direct Effect of FDI

\begin{tabular}{lllll}
\hline Dependent Variable: GDPPCGR - Sample (adjusted): 19882009 & & & \\
\hline C & ALL & HIGH & MID & LOW \\
\hline INF & 0.02 & 0.08 & 0.05 & 0.06 \\
& $(2.37)^{*}$ & $(1.91)^{*}$ & $(1.99)^{*}$ & $(0.95)$ \\
TRD & 0.00 & 0.00 & 0.00 & 0.00 \\
& $(-5.75)^{*}$ & $(0.14)$ & $(-3.54)^{*}$ & $(-4.77)^{*}$ \\
FDI & 0.00 & 0.00 & 0.00 & 0.00 \\
& $(2.77)^{*}$ & $(1.61)$ & $(3.63)^{*}$ & $(2.12)^{*}$ \\
R-squared & 0.00 & 0.00 & 0.00 & 0.00 \\
Adjusted R-squared & $(3.14)^{*}$ & $(3.47)^{*}$ & $(2.41)^{*}$ & $(0.48)$ \\
S.E. of regression & 0.07 & 0.05 & 0.10 & 0.28 \\
F-statistic & 0.06 & 0.04 & 0.09 & 0.24 \\
Prob(F-statistic) & 0.04 & 0.03 & 0.04 & 0.04 \\
Obs & 14.53 & 4.28 & 8.99 & 7.55 \\
\hline
\end{tabular}

Notes: t-values are in parentheses. The first column refers to the all countries that data are available. The rest columns refer to the sample of countries that categorized by income; high income, middle income, low income, respectively. 
Table 2a. The Direct Effect of Financial Development - All Countries

\begin{tabular}{|c|c|c|c|c|c|c|c|c|c|}
\hline \multicolumn{10}{|c|}{ Dependent Variable: GDPPCGR - Method: Pooled Least Squares - Sample(adjusted): 19882009} \\
\hline Variable & LLGDP & PCRDBGDP & STMKTCAP & STVALTRADED & STTURNOVER & PCRDBOFGDP & CBATA & BDGDP & FDGDP \\
\hline \multirow[t]{2}{*}{$\mathrm{C}$} & 0.017 & 0.013 & 0.022 & 0.016 & 0.018 & 0.012 & -0.006 & 0.021 & 0.021 \\
\hline & $(2.48)^{*}$ & $(1.58)$ & $(3.19)^{*}$ & $(2.33)^{*}$ & $(2.64)^{*}$ & $(1.56)$ & $(-0.43)$ & $(2.91)^{*}$ & $(2.89)^{*}$ \\
\hline \multirow[t]{2}{*}{ FINANCE } & -0.003 & -0.008 & 0.008 & -0.001 & 0.005 & -0.007 & -0.027 & -0.003 & -0.001 \\
\hline & $(-0.97)$ & $(-2.01)^{*}$ & $(2.23)^{*}$ & $(-0.09)$ & (1.76) & $(-2.07)^{*}$ & $(-1.66)$ & $(-0.58)$ & $(0.01)$ \\
\hline \multirow[t]{2}{*}{ INF } & 0.000 & 0.000 & 0.000 & 0.000 & 0.000 & 0.000 & 0.000 & 0.000 & 0.000 \\
\hline & $(-4.26)^{*}$ & $(-4.31)^{*}$ & $(-5.08)^{*}$ & $(-5.19)^{*}$ & $(-5.18)^{*}$ & $(-4.32)^{*}$ & $(-4.06)^{*}$ & $(-4.28)^{*}$ & $(-4.24)^{*}$ \\
\hline \multirow[t]{2}{*}{ TRD } & 0.000 & 0.000 & 0.000 & 0.000 & 0.000 & 0.000 & 0.000 & 0.000 & 0.000 \\
\hline & $(3.23)^{*}$ & $(3.45)^{*}$ & $(0.54)$ & $(0.63)$ & (1.56) & $(3.71)^{*}$ & $(1.97)^{*}$ & $(3.14)^{*}$ & $(3.12)^{*}$ \\
\hline $\mathrm{R}^{2}$ & 0.03 & 0.04 & 0.05 & 0.04 & 0.05 & 0.04 & 0.08 & 0.03 & 0.03 \\
\hline Adjusted $\mathrm{R}^{2}$ & 0.03 & 0.03 & 0.04 & 0.04 & 0.04 & 0.03 & 0.08 & 0.03 & 0.03 \\
\hline S.E. of regression & 0.03 & 0.03 & 0.03 & 0.03 & 0.03 & 0.03 & 0.04 & 0.03 & 0.03 \\
\hline F-statistic & 7.67 & 8.13 & 10.81 & 9.93 & 10.38 & 8.69 & 10.50 & 7.36 & 7.34 \\
\hline Prob(F-statistic) & 0.00 & 0.00 & 0.00 & 0.00 & 0.00 & 0.00 & 0.00 & 0.00 & 0.00 \\
\hline Obs & 974 & 966 & 982 & 1026 & 979 & 985 & 665 & 997 & 999 \\
\hline
\end{tabular}

Notes: t-values are in parentheses.

The financial market variables change with each column. LLDGP (Liquid Liabilities), PCRDBGDP (Private Credit by the Deposit Money Banks to GDP), STMKTCAP (Stock Market Capitalization Ratio to GDP), STVALTRADED (Stock Market Total Value Traded to GDP), STTURNOVER (Stock Market Turnover Ratio), PCRDBOFGDP (Private Credit by Deposit Money Banks and Other Financial Institutions to GDP), CBATA (Central Bank Assets to Total Financial Assets), BDGDP (Bank Deposits to GDP), FDGDP (Financial System Deposits to GDP).

Table 2b. The Direct Effect of Financial Development - High Income Countries

\begin{tabular}{lcccccccccc}
\hline Dependent Variable: GDPPCGR - Method: Pooled Least Squares - Sample(adjusted): 1988 & 2009 & & & \\
\hline Variable & LLGDP & PCRDBGDP & STMKTCAP & STVALTRADED & STTURNOVER PCRDBOFGDP & CBATA & BDGDP & FDGDP \\
\hline C & 0.0815 & 0.0861 & 0.0728 & 0.0725 & 0.0690 & 0.0949 & 0.0968 & 0.0968 & 0.0795 \\
& $(2.04)^{*}$ & $(2.21)^{*}$ & $(1.92)^{*}$ & $(1.91)^{*}$ & $(1.82)$ & $(1.26)$ & $(2.46)^{*}$ & $(0.18)$ & $(2.16)$ \\
FINANCE & -0.0034 & -0.0128 & 0.0102 & -0.0165 & -0.0060 & -0.8596 & -0.0093 & -0.0093 & -0.0031 \\
& $(-0.95)$ & $(-3.04)^{*}$ & $(2.53)^{*}$ & $(-0.46)$ & $(-1.89)$ & $(-4.96)^{*}$ & $(-1.7)$ & $(-1.7)$ & $(-0.77)$ \\
INF & 0.0000 & -0.0003 & 0.0003 & 0.0000 & 0.0000 & 0.0009 & -0.0001 & -0.0001 & 0.0000 \\
& $(0.02)$ & $(-0.64)$ & $(0.82)$ & $(0.13)$ & $(-0.1)$ & $(0.94)$ & $(-0.25)$ & $(-0.25)$ & $(0.05)$ \\
TRD & 0.0001 & 0.0001 & 0.0000 & 0.0002 & 0.0001 & 0.0001 & 0.0001 & 0.0001 & 0.0001 \\
& $(1.93)^{*}$ & $(2.35)^{*}$ & $(-0.5)$ & $(0.58)$ & $(2.39)^{*}$ & $(1.52)$ & $(2.25)^{*}$ & $(2.25)^{*}$ & $(1.97)^{*}$ \\
R & 0.0128 & 0.0338 & 0.0276 & 0.0113 & 0.0203 & 0.2116 & 0.0190 & 0.0190 & 0.0134 \\
Adjusted R & 0.0029 & 0.0237 & 0.0176 & 0.0017 & 0.0105 & 0.1803 & 0.0092 & 0.0092 & 0.0035 \\
S.E. of regression & 0.0251 & 0.0251 & 0.0244 & 0.0248 & 0.0249 & 0.0219 & 0.0249 & 0.0249 & 0.0250 \\
F-statistic & 12.874 & 33.457 & 27.578 & 11.735 & 20.696 & 22.111 & 19.365 & 19.365 & 13.590 \\
Prob(F-statistic) & 0.2743 & 0.0104 & 0.0276 & 0.3219 & 0.0840 & 11.887 & 0.1036 & 0.1036 & 0.2475 \\
Obs & 501 & 488 & 494 & 516 & 505 & 206 & 506 & 506 & 506 \\
\hline
\end{tabular}

Notes: t-values are in parentheses. See notes of Table $2 \mathrm{a}$ for definitions of the variables 
Table 2c. The Direct Effect of Financial Development - Middle Income Countries

\begin{tabular}{lcccccccccccc}
\hline Dependent Variable: GDPPCGR - Method: Pooled Least Squares - Sample(adjusted): 1988 & 2009 & & & \\
\hline Variable & LLGDP & PCRDBGDP & STMKTCAP & STVALTRADED & STTURNOVER PCRDBOFGDP & CBATA & BDGDP & FDGDP \\
\hline C & 0.0225 & 0.0206 & 0.0367 & 0.0216 & 0.0204 & 0.0076 & -0.0159 & 0.0368 & 0.0303 \\
& $(0.84)$ & $(0.83)$ & $(1.47)$ & $(0.9)$ & $(0.84)$ & $(0.31)$ & $(-0.49)$ & $(1.48)$ & $(1.25)$ \\
FINANCE & -0.0149 & -0.0072 & 0.0147 & 0.0230 & 0.0129 & -0.0084 & -0.0186 & -0.0149 & -0.0049 \\
& $(-1.87)$ & $(-0.74)$ & $(1.97)^{*}$ & $(1.07)$ & $(1.91)^{*}$ & $(-1.07)$ & $(-0.97)$ & $(-1.37)$ & $(-0.61)$ \\
INF & 0.0004 & 0.0003 & 0.0002 & 0.0002 & 0.0002 & 0.0003 & 0.0002 & 0.0002 & 0.0001 \\
& $(-3.67)^{*}$ & $(-3.46)^{*}$ & $(-3.81)^{*}$ & $(-4.08)^{*}$ & $(-4.21)^{*}$ & $(-3.49)^{*}$ & $(-3.67)^{*}$ & $(-3.65)^{*}$ & $(-3.5)^{*}$ \\
TRD & 0.0004 & 0.0003 & 0.0001 & 0.0001 & 0.0002 & 0.0003 & 0.0003 & 0.0003 & 0.0003 \\
& $(4.21)^{*}$ & $(3.71)^{*}$ & $(1.04)$ & $(0.42)$ & $(2.24)^{*}$ & $(3.84)^{*}$ & $(3.18)^{*}$ & $(3.91)^{*}$ & $(3.68)^{*}$ \\
R & 0.0787 & 0.0673 & 0.0841 & 0.0785 & 0.0847 & 0.0711 & 0.0916 & 0.0698 & 0.0660 \\
Adjusted R & 0.0685 & 0.0572 & 0.0744 & 0.0689 & 0.0749 & 0.0611 & 0.0797 & 0.0600 & 0.0561 \\
S.E. of regression & 0.0383 & 0.0395 & 0.0395 & 0.0388 & 0.0390 & 0.0390 & 0.0408 & 0.0389 & 0.0391 \\
F-statistic & 76.925 & 66.418 & 86.520 & 81.831 & 86.485 & 70.811 & 77.349 & 70.910 & 67.107 \\
Prob(F-statistic) & 0.0000 & 0.0000 & 0.0000 & 0.0000 & 0.0000 & 0.0000 & 0.0000 & 0.0000 & 0.0000 \\
Obs & 365 & 373 & 382 & 389 & 379 & 375 & 312 & 383 & 385 \\
\hline
\end{tabular}

Notes: t-values are in parentheses. See notes of Table $2 \mathrm{a}$ for definitions of the variables

Table 2d. The Direct Effect of Financial Development - Low Income Countries

\begin{tabular}{lcccccccccccccc}
\hline Dependent Variable: GDPPCGR - Method: Pooled Least Squares - Sample(adjusted): 1988 & 2009 & & & & \\
\hline Variable & LLGDP & PCRDBGDP & STMKTCAP & STVALTRADED & STTURNOVER PCRDBOFGDP & CBATA & BDGDP & FDGDP \\
\hline C & 0.0898 & 0.0858 & 0.0637 & 0.0659 & 0.0512 & 0.0576 & -0.1254 & 0.0733 & 0.0946 \\
& $(1.56)$ & $(1.46)$ & $(1.1)$ & $(1.17)$ & $(0.92)$ & $(0.92)$ & $(-1.29)$ & $(1.32)$ & $(1.5)$ \\
FINANCE & 0.0625 & 0.0513 & 0.0150 & 0.3530 & -0.0058 & -0.0299 & -0.0137 & 0.0662 & 0.0433 \\
& $(1.22)$ & $(0.76)$ & $(0.64)$ & $(0.5)$ & $(-1.01)$ & $(-0.51)$ & $(-0.23)$ & $(1.19)$ & $(0.78)$ \\
INF & -0.0005 & -0.0006 & -0.0004 & -0.0004 & -0.0004 & -0.0007 & -0.0002 & -0.0005 & -0.0006 \\
& $(-2.04)^{*}$ & $(-2.38)^{*}$ & $(-4.84)^{*}$ & $(-5.62)^{*}$ & $(-5.88)^{*}$ & $(-3.11)^{*}$ & $(-1.81)$ & $(-1.89)$ & $(-2.65)^{*}$ \\
TRD & 0.0003 & 0.0003 & 0.0003 & 0.832 & 0.0006 & 0.0004 & 0.0027 & 0.0002 & 0.0003 \\
& $(1.65)$ & $(2.02)^{*}$ & $(2.32)^{*}$ & $(0.54)$ & $(2.26)^{*}$ & $(2.52)^{*}$ & $(1.04)$ & $(1.43)$ & $(2.07)^{*}$ \\
R & 0.2139 & 0.2052 & 0.3441 & 0.3353 & 0.3488 & 0.2020 & 0.3202 & 0.2133 & 0.2055 \\
Adjusted R & 0.1746 & 0.1654 & 0.3129 & 0.3040 & 0.3178 & 0.1621 & 0.2325 & 0.1740 & 0.1657 \\
S.E. of regression & 0.0313 & 0.0314 & 0.0317 & 0.0321 & 0.0316 & 0.0315 & 0.0396 & 0.0313 & 0.0314 \\
F-statistic & 34.553 & 31.257 & 34.430 & 30.145 & 30.943 & 31.879 & 18.055 & 32.416 & 39.546 \\
Prob(F-statistic) & 15.987 & 15.875 & 16.597 & 15.555 & 16.599 & 15.671 & 20.307 & 15.684 & 15.968 \\
Obs & 95 & 93 & 99 & 101 & 99 & 95 & 66 & 95 & 95 \\
\hline
\end{tabular}

Notes: t-values are in parentheses. See notes of Table 2a for definitions of the variables

Through the above regressions, we evaluated the direct impact of financial market variables on economic growth regardless of FDI. Now, we turn to examine through the estimation of regression model (3) the interaction between the financial development proxy variables and FDI and its effect on economic growth. First, we use the whole sample of 73 countries. The results are reported in Table 3a. Looking at the results we observe that the interaction FINANCE*FDI term is statistically significant for of all financial development proxies except CBATA. All variables, both 
intermediaries and stock market variables have positive effect on growth. However, the coefficients are fairly small to account for substantial effect on economic growth as was anticipated. Also, as it was expected from the theory, INF and TRD have in most cases significant negative and positive coefficients respectively. These results provide strong evidence in favor of the idea that neither FDI nor financial development itself is enough to promote growth and the co-existence of the two is what is necessary.

Next, we re-estimated model (3) for the three different sub-groups in order to examine similarities and differences among the different sub-groups. The results for the high-income group are presented in Table $3 b$. These results are not at all different from those of the previous Table in terms of our primary indicator: the interaction term FINANCE*FDI. Both the financial intermediary proxy variables and the stock market proxy variables are highly significant (except again CBATA). It is important to mention that while the direct FDI effect was positive but small and the direct financial development effect negative and insignificant, the combined effect seems to be very strong and positive. Therefore, we conclude that the FDI and the level of financial development, jointly, have a positive effect on growth for the high-income group (including countries such as Cyprus, Israel, Malta, Singapore etc.). These findings are consistent with the earlier studies and confirm partially the hypothesis that a certain level of financial development is an important prerequisite for FDI to have a positive effect on growth (as emphasized by Hermes and Lensink, 2003).

The regressions results for the middle-income countries (Latin American countries as Brazil, Argentina, Paraguay and so on) are reported in Table 3c. Here we see that the interaction term is always positive but never significant (with the exception of STMKTCAP). Therefore, the consequence of FDI channeling through financial development is an ambiguous matter for the middle-income countries. The positive and significant coefficient of the stock market capitalization variable probably suggests that the most likely FDI to growth effect comes through the development of the stock markets. This result can be interpreted as evidence for the policy makers to focus on the stock market development in order to be able to attract more FDI and hence higher growth rates in the economy.

Finally, regarding the low-income group (among them Togo, Sudan, Pakistan etc.) the results are presented in Table 3d. Not surprisingly, the interaction variable term is found to be statistically insignificant. So our findings might support the view that insufficient level of financial market development can reduce the absorptive capability of the host country.

Table 3a. The Interactive Effect of FDI and Financial Development - All Countries

\begin{tabular}{lccccccccccc}
\hline Dependent Variable: GDPPCGR - Method: Pooled Least Squares - Sample(adjusted): 1988 & 2009 & & & & \\
\hline Variable & LLGDP & PCRDBGDP & STMKTCAP & STVALTRADED & STTURNOVER PCRDBOFGDP & CBATA & BDGDP & FDGDP \\
\hline C & 0.0180 & 0.0199 & 0.0212 & 0.0154 & 0.0200 & 0.0178 & -0.0191 & 0.0220 & 0.0219 \\
& $(2.45)^{*}$ & $(2.62)^{*}$ & $(2.89)^{*}$ & $(2.19)^{*}$ & $(2.75)^{*}$ & $(2.41)^{*}$ & $(-1.42)$ & $(3.02)^{*}$ & $(-3.08)^{*}$ \\
FINANCE*FDI & 0.0008 & 0.0007 & 0.0009 & 0.0011 & 0.0017 & 0.0008 & 0.0043 & 0.0008 & 0.0008 \\
& $(2.76)^{*}$ & $(2.33)^{*}$ & $(3.56)^{*}$ & $(2.24)^{*}$ & $(2.87)^{*}$ & $(2.66)^{*}$ & $(0.98)$ & $(2.53)^{*}$ & $(2.77)^{*}$ \\
INF & 0.0007 & 0.0004 & 0.0003 & 0.0007 & 0.0005 & 0.0006 & 0.0004 & 0.0008 & 0.0003 \\
& $(-4.04)^{*}$ & $(-4.01)^{*}$ & $(-4.88)^{*}$ & $(-5.01)^{*}$ & $(-4.94)^{*}$ & $(-4.03)^{*}$ & $(-3.83)^{*}$ & $(-4.09)^{*}$ & $(-4.07)^{*}$ \\
TRD & 0.0001 & 0.0001 & 0.0001 & 0.0000 & 0.0000 & 0.0001 & 0.0001 & 0.0001 & 0.0001 \\
& $(2.62)^{*}$ & $(2.49)^{*}$ & $(1.76)$ & $(0.92)$ & $(1.19)$ & $(2.37)^{*}$ & $(2.52)^{*}$ & $(2.68)^{*}$ & $(2.64)^{*}$ \\
R & 0.0438 & 0.0399 & 0.0572 & 0.0481 & 0.0525 & 0.0433 & 0.0787 & 0.0403 & 0.0418 \\
Adjusted R & 0.0390 & 0.0351 & 0.0526 & 0.0437 & 0.0478 & 0.0387 & 0.0703 & 0.0356 & 0.0372 \\
S.E. of regression & 0.0327 & 0.0337 & 0.0337 & 0.0332 & 0.0334 & 0.0331 & 0.0387 & 0.0331 & 0.0332 \\
F-statistic & 92.693 & 83.012 & 123.111 & 107.911 & 111.965 & 92.531 & 93.705 & 86.936 & 90.582 \\
Prob(F-statistic) & 0.0000 & 0.0000 & 0.0000 & 0.0000 & 0.0000 & 0.0000 & 0.0000 & 0.0000 & 0.0000 \\
Obs & 915 & 904 & 916 & 959 & 913 & 922 & 544 & 934 & 936 \\
\hline
\end{tabular}

Notes: $\mathrm{t}$-values are in parentheses. See notes of Table 2a for definitions of the variables. FDI is interacted with various financial market variables. 
Table 3b. The Interactive Effect of FDI and Financial Development - High Income Countries

\begin{tabular}{lcccccccccc}
\hline Dependent Variable: GDPPCGR - Method: Pooled Least Squares - Sample(adjusted): 1988 2009 & & & \\
\hline Variable & LLGDP & PCRDBGDP & STMKTCAP & STVALTRADED & STTURNOVER & PCRDBOFGDP & CBATA & BDGDP & FDGDP \\
\hline C & 0.0709 & 0.0752 & 0.0664 & 0.0750 & 0.0564 & 0.0742 & -0.0424 & 0.0780 & 0.0768 \\
& $(1.61)$ & $(1.74)$ & $(1.57)$ & $(1.78)$ & $(1.32)$ & $(1.74)$ & $(-0.47)$ & $(1.83)$ & $(1.81)$ \\
FINANCE*FDI & 0.0007 & 0.0007 & 0.0007 & 0.0012 & 0.0018 & 0.0008 & 0.0143 & 0.0007 & 0.0008 \\
& $(3.03)^{*}$ & $(2.95)^{*}$ & $(3.83)^{*}$ & $(3.24)^{*}$ & $(3.83)^{*}$ & $(3.44)^{*}$ & $(0.42)$ & $(2.94)^{*}$ & $(3.21)^{*}$ \\
INF & 0.0001 & 0.0001 & 0.0002 & 0.0001 & 0.0001 & 0.0001 & -0.0001 & 0.0001 & 0.0001 \\
& $(0.36)$ & $(0.29)$ & $(0.53)$ & $(-0.03)$ & $(0.34)$ & $(0.34)$ & $(-0.07)$ & $(0.26)$ & $(0.29)$ \\
TRD & 0.0006 & 0.0008 & 0.0006 & 0.0005 & 0.0003 & 0.0006 & 0.0008 & 0.0006 & 0.0009 \\
& $(1.42)$ & $(1.31)$ & $(0.94)$ & $(-0.37)$ & $(0.07)$ & $(1.16)$ & $(0.78)$ & $(1.55)$ & $(1.48)$ \\
$\mathrm{R}^{2}$ & 0.0367 & 0.0359 & 0.0527 & 0.0395 & 0.0529 & 0.0443 & 0.0209 & 0.0364 & 0.0406 \\
Adjusted R & 0.0260 & 0.0249 & 0.0420 & 0.0292 & 0.0422 & 0.0338 & -0.0190 & 0.0259 & 0.0301 \\
S.E. of regression & 0.0253 & 0.0257 & 0.0247 & 0.0250 & 0.0246 & 0.0252 & 0.0248 & 0.0252 & 0.0252 \\
F-statistic & 34.440 & 32.506 & 49.279 & 38.529 & 49.400 & 42.303 & 42.725 & 34.570 & 38.730 \\
Prob(F-statistic) & 0.0089 & 0.0123 & 0.0007 & 0.0044 & 0.0007 & 0.0023 & 0.9471 & 0.0086 & 0.0043 \\
Obs & 467 & 454 & 459 & 480 & 459 & 470 & 203 & 471 & 471 \\
\hline
\end{tabular}

Notes: t-values are in parentheses. See notes of Table $2 \mathrm{a}$ for definitions of the variables. FDI is interacted with various financial market variables.

Table 3c. The Interactive Effect of FDI and Financial Development - Middle Income Countries

\begin{tabular}{lcccccccccc}
\hline Dependent Variable: GDPPCGR - Method: Pooled Least Squares - Sample(adjusted): 1988 2009 & & & \\
\hline Variable & LLGDP & PCRDBGDP & STMKTCAP & STVALTRADED & STTURNOVER & PCRDBOFGDP & CBATA & BDGDP & FDGDP \\
\hline $\mathrm{C}$ & 0.0234 & 0.0313 & 0.0584 & 0.0317 & 0.0327 & 0.0175 & -0.0126 & 0.0418 & 0.0436 \\
& $(0.87)$ & $(1.19)$ & $(2.18)$ & $(1.25)$ & $(1.26)$ & $(0.66)$ & $(-0.38)$ & $(1.64)$ & $(1.71)$ \\
FINANCE*FDI & 0.0017 & 0.0012 & 0.0032 & 0.0006 & 0.0037 & 0.0009 & 0.0028 & 0.0023 & 0.0020 \\
& $(1.31)$ & $(0.74)$ & $(2.81)^{*}$ & $(0.22)$ & $(1.07)$ & $(0.66)$ & $(0.54)$ & $(1.32)$ & $(1.33)$ \\
INF & 0.0000 & 0.0000 & 0.0000 & 0.0000 & 0.0000 & 0.0000 & 0.0000 & 0.0000 & 0.0000 \\
& $(-3.2)^{*}$ & $(-3.22)^{*}$ & $(-3.69)^{*}$ & $(-3.92)^{*}$ & $(-3.86)^{*}$ & $(-3.22)^{*}$ & $(-3.49)^{*}(-3.24)^{*}(-3.23)^{*}$ \\
TRD & 0.0003 & 0.0003 & 0.0001 & 0.0003 & 0.0002 & 0.0003 & 0.0003 & 0.0003 & 0.0003 \\
& $(3.16)^{*}$ & $(3.24)^{*}$ & $(1.31)$ & $(1.81)$ & $(1.97)$ & $(3.18)^{*}$ & $(3.58)^{*}(3.14)^{*}$ & $(3.06)^{*}$ \\
$\mathrm{R}^{2}$ & 0.0756 & 0.0675 & 0.0954 & 0.0759 & 0.0786 & 0.0683 & 0.0882 & 0.0704 & 0.0704 \\
Adjusted R & 0.0647 & 0.0566 & 0.0852 & 0.0657 & 0.0680 & 0.0576 & 0.0757 & 0.0599 & 0.0600 \\
S.E. of regression & 0.0389 & 0.0403 & 0.0400 & 0.0396 & 0.0398 & 0.0398 & 0.0415 & 0.0397 & 0.0397 \\
F-statistic & 69.302 & 62.222 & 93.099 & 73.940 & 74.614 & 63.431 & 70.413 & 67.005 & 67.427 \\
Prob(F-statistic) & 0.0000 & 0.0001 & 0.0000 & 0.0000 & 0.0000 & 0.0001 & 0.0000 & 0.0000 & 0.0000 \\
Obs & 444 & 449 & 458 & 465 & 455 & 451 & 396 & 459 & 461 \\
\hline
\end{tabular}

Notes: t-values are in parentheses. See notes of Table 2a for definitions of the variables. FDI is interacted with various financial market variables. 
Table 3d. The Interactive Effect of FDI and Financial Development - Low Income Countries

\begin{tabular}{lccccccccc}
\hline Dependent Variable: GDPPCGR - Method: Pooled Least Squares - Sample(adjusted): 1988 2009 & & & \\
\hline Variable & LLGDP & PCRDBGDP & STMKTCAP & STVALTRADED & STTURNOVER PCRDBOFGDP & CBATA & BDGDP & FDGDP \\
\hline C & 0.0750 & 0.0810 & 0.0552 & 0.0648 & 0.0469 & 0.0813 & -0.1234 & 0.0742 & 0.0781 \\
& $(1.31)$ & $(1.4)$ & $(0.96)$ & $(1.11)$ & $(0.81)$ & $(1.4)$ & $(-1.23)$ & $(1.29)$ & $(1.36)$ \\
FINANCE*FDI & 0.0070 & 0.0128 & 0.0146 & -0.0062 & -0.0078 & 0.0085 & 0.0092 & 0.0082 & 0.0062 \\
& $(0.68)$ & $(0.7)$ & $(1.21)$ & $(-0.11)$ & $(-1.07)$ & $(0.63)$ & $(0.71)$ & $(0.49)$ & $(0.58)$ \\
INF & -0.0007 & -0.0007 & -0.0004 & -0.0003 & -0.0004 & -0.0007 & -0.0002 & -0.0007 & -0.0007 \\
& $(-3.07)^{*}$ & $(-3.06)^{*}$ & $(-5.07)^{*}$ & $(-4.73)^{*}$ & $(-5.02)^{*}$ & $(-3.07)^{*}$ & $(-1.61)(-3.03)^{*}(-3.07)^{*}$ \\
TRD & -0.0007 & 0.0003 & 0.0003 & 0.0004 & 0.0006 & 0.0003 & 0.0029 & 0.0003 & 0.0003 \\
& $(-3.07)^{*}$ & $(1.82)$ & $(1.95)^{*}$ & $(0.85)$ & $(2.03)^{*}$ & $(1.86)$ & $(1.1)$ & $(1.76)$ & $(1.84)$ \\
$\mathrm{R}^{2}$ & 0.1804 & 0.1807 & 0.2943 & 0.2745 & 0.2914 & 0.1797 & 0.2844 & 0.1780 & 0.1791 \\
Adjusted R & 0.1373 & 0.1376 & 0.2581 & 0.2378 & 0.2551 & 0.1366 & 0.1857 & 0.1348 & 0.1359 \\
S.E. of regression & 0.0320 & 0.0320 & 0.0323 & 0.0330 & 0.0323 & 0.0320 & 0.0406 & 0.0320 & 0.0320 \\
F-statistic & 39.453 & 31.915 & 39.012 & 38.664 & 30.243 & 37.924 & 16.381 & 36.432 & 35.534 \\
Prob(F-statistic) & 16.187 & 16.183 & 15.989 & 15.321 & 16.356 & 16.153 & 20.585 & 16.093 & 16.149 \\
Obs & 101 & 101 & 123 & 124 & 123 & 101 & 84 & 101 & 101 \\
\hline
\end{tabular}

Notes: t-values are in parentheses. See notes of Table $2 \mathrm{a}$ for definitions of the variables. FDI is interacted with various financial market variables.

\section{Summary and Concluding Remarks}

The contribution of this study is to shed more light on the issue of FDI and financial development interaction and its possible effect on the economic growth of the host country. The idea, simply is that the more developed the financial system is, the more absorptive capacity the country has for FDI and therefore the economic growth is affected positive and substantially. The study investigated empirically the role the local financial markets in enhancing the positive relationship between FDI and economic growth.

When we looked at the direct effect of the FDI, we found that it is significant for the high and middle-income countries rather than for the low-income countries. On the other hand, inconsistent with the literature, the direct effect of the financial market development was negatively correlated with the growth rate, even for high-income countries, which might indicate that financial markets are insufficient to make substantial contribution to the economic growth of the countries under our empirical examination regardless of the FDI inflows.

However, when we examined the combined FDI and financial development effect through an interaction term, the results suggested that it is important for the growth of the economies under examination. More specifically, we found a significant and positive effect on growth for the high-income group and for all financial development proxies. For the middle-income group only the stock market development proxies have a positive and significant effect, while with regards to the low-income group, we found no significant results at all.

Thus, the results confirm that there is a positive and statistically significant relationship between FDI, financial development and economic growth and that this link is obvious for especially high-income countries, which have a well-established financial system, while the relationship is weaker for the low-income countries, which have a less-functioning financial system.

\section{References}

Alfaro, L., C., A., Kalemi-Ozcan, S., \& Sayek, S. (2004). FDI and Economic Growth: The Role of Local Financial Markets. Journal of International Economics, 64(1), 89-112.

Aitken, B. J., \& Harrison, A., (1999). Do Domestic Firms Benefit from Direct Foreign Investment? Evidence from Venezuela. American Economic Review, 89, 605-618.

Beck, T., Demirgüç-Kunt, A., \& Levine, R. (2000). A New Database on Financial Development and Structure. World Bank Economic Review, 14, 97-605 
Blomström, M., \& Persson, H. (1983). Foreign Investment and Spillover Efficiency in an Underdeveloped Economy: Evidence from the Mexican Manufacturing Industry. World Development, 11(6), 493-501.

Borensztein, E., De Gregorio, J., \& Lee, J. W. (1998). How Does Foreign Direct Investment Affect Economic Growth?” Journal of International Economics, 45, 115-35.

Boyd, J., H., Levine, R., \& Smith, B. D. (2001). The impact of inflation on financial sector performance. Journal of Monetary Economics, 479(2), 221-248.

De Mello, L. R. (1999). Foreign Direct Investment-Led Growth: Evidence from Time Series and Panel Data. Oxford Economic Papers, 51, 133-151.

Greenwood, J., \& Jovanovic, B. (1990). Financial Development, Growth and the Distribution of Income. Journal of Political Economy, 98(5), 1076-1107.

Haddad, M., \& Harrisson, A. E. (1993). Are There Positive Spillovers from Direct Foreign Investment? Evidence from Panel Data for Morocco. Journal of Development Economics, 42, 51-74.

Hermes, N., \& Lensink, R. (2003). Foreign Direct Investment, Financial Development and Economic Growth. The Journal of Development Studies, 40(1), 142-163

King, R., \& Levine, R. (1993a). Finance and Growth: Schumpeter Might be Right. Quarterly Journal of Economics, 108, 717-38.

King, R., \& Levine, R. (1993b). Finance, Entrepreneurship and Growth: Theory and Evidence. Journal of Monetary Economics, 32, 513-42.

Kokko, A., Tansini, R., \& Zejan, M. C. (1996). Local Technological Capability and Productivity Spillovers from FDI in the Uruguayan Manufacturing Sector. The Journal of Development Studies, 32(4), 602-11.

Levine, R., Beck, T., \& Loayza, N. (2000a). Finance and the Sources of Growth. Journal of Financial Economics, 58, 261-300.

Levine, R., Loayza, N., \& Beck, T. (2000b). Financial Intermediation and Growth: Causality and Causes. Journal of Monetary Economics, 46(1), 31-77.

Levine, R., \& Renelt, D. (1992). A Sensitivity Analysis of Cross-Country Growth Regressions. American Economic Review, 82(4), 942-63.

Levine, R., \& Zervos, S. (1998). Stock Markets, Banks and Economic Growth. American Economic Review, 88, 537-58.

Rajan, R. J., \& Zingales, L. (1998). Financial Dependence and Growth. American Economic Review, 88(3), 559-86.

Reisen, H., \& Soto, M. (2001). Which Types of Capital Inflows Foster Developing-Country Growth?" International Finance, 4(1)

Rodriguez-Clare, A., Larrain, F., \& Lopez-Calva, L. (2000). Intel: A Case Study of Foreign Direct Investment in Central America. Center for International Development, Harvard University Working Paper, 58.

Sjöholm, F. (1999). Productivity Growth in Indonesia: The Role of Regional Characteristics and Direct Foreign Investment. Economic Development and Cultural Change, 47(3), 559-84.

\section{(cc) $\mathrm{BY}$}

This work is licensed under a Creative Commons Attribution 3.0 License. 